\title{
市政工程施工管理存在的问题及解决策略
}

胡宝永 刘洋

中建宏图建设发展有限公司

DOI:10.32629/btr.v2i10.2584

[摘 要] 伴随社会经济的快速发展,特别是市场增值的基础上,城市内部不同类型建筑数量显著增加, 施工建设的作用也逐渐 凸显出来。特别是市政工程发展增进的过程中,更应高度重视施工管理的作用。究其原因,市政工程会对城市整体发展产生影 响,所以必须严格落实市政工作。市政工程管理不同于其他建设类工程,基于此,文章将市政工程施工管理作为主要研究内容, 重点阐述存在问题与解决策略, 希望有所帮助。

[关键词]市政工程; 施工管理; 问题; 解决策略

基于城市化建设速度的不断加快, 市政工程项目规模逐 渐扩大, 存在的问题随之增多。究其原因, 施工管理工作落实 不到位。在市政工程项目施工期间, 施工企业更强调施工进 度, 一味追赶工期, 导致施工质量无法满足标准要求。为此, 施工企业应高度重视市政工程施工管理存在的问题, 并提出 可行性较强的解决策略。

\section{1 市政工程施工管理存在的问题}

1. 1施工管理规范性缺失

施工管理不仅要强调施工现场质量监督, 同时也需要对 进度计划实施管理, 负责作业人员与机械设备的安排、拨付 工程款等等。在市政工程项目建设施工中, 人力成本占据较 大比重, 管理部门成员并不充足, 所以身兼数职的情况十分 常见。另外, 很多市政企业建设单位均为当地行政主管部门 亦或是授权单位, 受权利限制, 很难履行基本的建设程序 ${ }^{[1]}$ 。 加之监督力度不到位, 监督作用的发挥效果也差强人意。部 分工程项目的建设未结合规定程度完成许可证的办理, 只有 在部门检查时才会补办, 甚至有政府工程过度强调政绩, 对 施工工期与设计时间进行压缩, 最终致使项目设计功能不合 理亦或是质量问题诸多。除此之外, 监督部门忽视质量问题, 且监督企业权利不充分, 过于担忧与施工企业、业主单位关 系不理想, 因而不会切实地反映施工问题。

1.2施工质量问题突出

现代施工企业的质量管理存在诸多问题, 综合考虑市政 工程项目基本特点, 并未采取必要的安全措施, 且工作人员 安全意识薄弱, 增加了安全事故的发生几率。一旦安全事故 发生, 必然会对市政工程项目的运行产生不利影响, 经济损 失严重。与此同时, 部分建筑企业会采用内部项目承包制度, 或者是不具备相应资质, 导致质量管控与施工质量控制问题 逐渐凸显出来。除此之外, 很多市政工作人员不具备丰富的 专业知识, 在图纸设计方面缺乏规范性, 设计变更相对随意, 标准滞后与空缺问题突出 ${ }^{[2]}$ 。

1. 3 机械设备利用效果差强人意

除人力成本外, 施工建设施工的机械设备在总成本中的 占比也很大。在成本管理中, 有必要强调机械管理的作用。
但是, 目前很多施工企业并未参考项目具体需求与市场行情 对机械设备进行采购, 甚至会因购买的盲目性而出现设备闲 置的情况。正是因为计划管理与统筹机制不合理, 所以设备 利用效率偏低。加之设备管理不合理, 使用与维修不及时, 均对设备使用时间产生了不利影响。此外, 很多施工作业人 员的素质水平不达标, 难以根据规定要求对机械设备加以利 用, 直接增加了机械设备的使用成本。

\section{2 解决市政工程施工管理问题的有效策略}

根据以上对市政工程施工管理问题的研究与分析, 为不 断优化工程项目的施工管理效果, 需结合实际需求, 科学合 理地采取解决策略, 为市政工程项目的施工管理工作落实提 供有价值的参考依据。

2.1施工过程的把控

对施工质量产生影响的主要因素就是施工过程, 要想更 好地把控项目的质量, 就不应在施工事故发生后实施管理, 而是要提前采取预防措施, 针对工作人员实施岗前培训, 组织 管理工作人员进行专业学习。参考相关规范要求开展工艺操 作, 为工艺质量的提高奠定坚实基础。另外, 控制过程为操作 提供保障。只有对施工操作人员、施工机械设备、环境、方 法与材料等展开系统控制, 才能够为质量水平的提升提供必 要前提 ${ }^{[3]}$ 。在此基础上, 对过程活动效果展开系统检查。对质 量进行判断的基本标准就是过程活动效果, 为此, 应积极开 展质量检测工作, 落实质量分析工作, 对质量动态加以掌握, 尽量保证工艺活动质量与规范要求相适应。在此基础上, 对 质量控制点加以设置, 便于在特定时间与条件下强化管理力 度, 保证施工过程始终处于被控制的状态。

\section{2 增强安全意识水平}

对于市政工程项目而言, 提高管理工作人员素质水平是 优化施工人员专业知识与安全意识的前提。所以, 必须积极 开展管理工作人员培训考核, 才能够使其熟练掌握并灵活运 用安全知识与方法。在培训期间, 要综合考虑不同工作人员 性质与要求, 强调技术教育与技能培训的重要性 ${ }^{[4]}$ 。在适应 施工要求以后, 要参考设计要求采购材料与相关设备, 并结 合施工图纸要求落实施工建设。 


\section{3 施工技术数据管理的改进}

由于施工技术数据管理相对复杂, 且会直接影响市政工 程项目的质量, 所以要不断加大管理力度, 以全面增强工作 有效性。对施工技术数据管理加以完善的基础上,应确保数 据可靠, 并对施工技术数据信息进行必要监督。对技术文档 的准备过程与要求进行系统审查, 实现数据管理方法的全面 优化, 通过系统化管理对原始数据进行记录。另外, 要创建专 门施工技术数据管理机构, 对文件进行定期整理与存档。

\section{4 提高施工安全性}

施工安全工程是市政工程的重要组成, 因市政工程本身 复杂性突出, 在施工期间需要较长周期且环境复杂, 具有较 高的机械化程度, 直接增加了施工安全问题的出现几率。但 最重要的就是要具备安全安全管理机制, 更好地落实安全责 任。此外, 要健全奖惩机制, 对安全指标较高的部门予以奖励, 合理制定处罚标准, 进一步增强管理效果。在此基础上, 要对 施工现场予以及时检查, 从根本上消除安全隐患 ${ }^{[5]}$ 。

在科学化管理的同时, 要根据标准要求完成施工作业。 另外, 要强调安全教育的重要作用, 并实施安全跟踪工作。建 筑任务安全施工是施工进度的有效表现形式。通过系统化事 故预防工作的开展, 强调细节工作, 以保证施工质量。在施工 材料选择方面, 需要对常规制造商进行联系, 材料在入场前 需强调检验质量的重要性。如果是钢筋则要开展弯曲与拉伸 试验, 而混凝土则需接受坉落度试验, 在全部材料力学性能 试验完成后, 要出具产品合格证明。贯彻落实施工建设期间, 对上部结构的确定需要以基础施工为主, 对地下水位进行测 量, 合理采用防水措施, 以免地下水对地基造成侵蚀 ${ }^{[6]}$ 。特别 是重要环节施工, 技术负责人员与安全人员都要反复检查并 记录, 在安全隐患发生的时候向更高级别及时上报。另外, 不管环境如何, 都必须强调施工的安全。一旦天气温度过高 亦或是过低, 均需对不同类型材料加以考虑。

2.5项目实施步骤的全面落实

在市政工程项目施工建设期间, 需强调施工步骤的重要 性, 对各环节加以把握, 保证项目管理与实际业务的有效协 调, 对项目管理各项任务分步骤落实。众所周知, 市政工程所 涉及的范围十分广泛且情况复杂, 具有较大的工程难度, 所
以全面管理与精细管理难度较大, 且施工企业内部绝大多数 工作人员也不具备管理专业知识 ${ }^{[7]}$ 。通常情况下, 需要系统 研究并分析项目, 对管理过程加以分析, 确定针对性管理措 施, 在技术与经济层面对市政工程施工项目可行性展开深入 研究。另外, 要对成本加以控制, 积极开展成本预算工作, 强 调施工项目进展。积极开展全面质量管理工作, 并在实践期 间灵活应变, 保证项目施工建设信息的传递与管理效果达 标。在此基础上, 应落实项目施工评议工作, 系统总结工程项 目优劣势, 进一步推动项目的顺利进行, 综合考虑施工状况, 对项目施工方案做出必要调整。

\section{3 结束语}

综上所述, 在市政工程项目管理工作开展的过程中, 施 工质量管理发挥着重要作用。然而, 受工程项目自身特点的 影响, 直接增加了市政工程施工质量管理的复杂性与繁重性, 难以确保施工建设的质量。为此, 在实践过程中, 为确保市政 工程项目建设质量, 就必须了解存在的问题, 积极深入项目 施工现场, 严格检查工程项目各施工环节, 对问题及时发现 并加以改进。只有这样, 才能够促进市政工程项目的顺利开 展, 保证市政工程项目施工管理的国际化发展。

\section{[参考文献]}

[1]王辉,谢章莉.浅谈加强市政工程施工管理提高市政 工程质量[J].装饰装修天地,2019,(16):320.

[2]王睿.探究如何加强市政工程施工技术与管理措施 [J].建材与装饰,2019,(26):194-195.

[3]贾克良.市政工程施工质量管理中存在的问题和对策 探析[J].建材发展导向(上),2019,17(8):345.

[4]贾鹏超.市政工程施工现场管理存在的问题与对策 [J].建筑工程技术与设计,2019,(19):2942.

[5]蔡金田.市政工程施工质量管理中的问题和对策[J]. 建筑工程技术与设计,2019,(18):2766。

[6]陈睛睛.市政工程施工质量管理中存在的问题和对策 [J].装饰装修天地,2019,(15):121.

[7]何国良。市政园林绿化工程施工管理的问题及措施 [J].建筑工程技术与设计,2019,(17):5786. 